\title{
Monitoring plaque composition: is it worthwile?
}

\author{
Arnoud van der Laarse $\cdot$ Ernst E. van der Wall
}

Received: 31 October 2008/Accepted: 31 October 2008/Published online: 27 November 2008

(C) The Author(s) 2008. This article is published with open access at Springerlink.com

In the current issue of the International Journal of Cardiovascular Imaging, Worthley et al. performed a study in New Zealand White rabbits that were fed a $0.2 \%$ cholesterol-containing diet for 9 months [1]. At the end of this period a group of rabbits continued having this diet (progression group) for 6 months and a group of rabbits received a normal rabbit diet for 6 months (regression group). At the start of the experiment all rabbits underwent aortic denudation from the aortic arch to the iliac bifurcation by a Fogarty embolectomy catheter passing four times through the lumen from the aortic arch to the iliac bifurcation while inflated.

Using ${ }^{18}$ fluoro-deoxyglucose positron emission tomography $\left({ }^{18}\right.$ FDG-PET $)$ the authors imaged the macrophages in the aortic plaques at two moments i.e. at the end of the common 9 months period of $0.2 \%$ cholesterol-containing diet, and 6 months later at the end of the progression or regression period. Immediately prior to ${ }^{18}$ FDG-PET imaging, aortic localization was defined by cardiovascular magnetic resonance imaging (CMR). Thirty minutes after

Editoral comments on the paper of Worthley et al. entitled "In vivo noninvasive serial monitoring of FDG-PET progression and regression in a rabbit model of atherosclerosis" (doi:10.1007/s10554-008-9377-2).

A. van der Laarse · E. E. van der Wall ( $₫)$ Department of Cardiology, Leiden University Medical Center, P.O. Box 9600, Leiden, The Netherlands e-mail: e.e.van_der_wall@lumc.nl intravenous administration of ${ }^{18} \mathrm{FDG}$, a 30 minute emission scan was obtained. Uptake of ${ }^{18}$ FDG by the aortic wall was expressed as the ratio of aortic uptake/blood pool activity. Per aorta a total of 25 consecutive slices were obtained which were pairwise analyzed using the images taken at the start and at the end of the period under study. The results demonstrated a progressive increase in aortic ${ }^{18} \mathrm{FDG}$ uptake in the progression group (from 0.57 to 0.68 , $P=0.001)$ and a decrease of aortic ${ }^{18}$ FDG uptake in the regression group (from 0.67 to $0.53, P=0.0001$ ).

Although these results provide highly significant results despite the low number of rabbits per group ( $n=4$ in progression and regression groups), the data representing the aortic uptake/blood pool activity obtained before and after the period under study show a broad overlap. Unfortunately, the graphs lack lines between the two values from the same rabbit. Secondly, it is regrettable that the initial values of aortic uptake/blood pool activity of the rabbits in the progression and the regression groups differ from each other, while both groups had the same atherogenic diet for 9 months.

Nevertheless, this study is important for several reasons: first-as a proof of concept -, in vivo ${ }^{18}$ FDGPET imaging of large vascular structures that are subject to an atherogenic stimulus or relieved from an atherogenic stimulus appears feasible; second, since macrophages are primarily responsible for the ${ }^{18} \mathrm{FDG}$ uptake in the atherosclerotic aortic wall [2,3], in vivo ${ }^{18}$ FDG-PET imaging of a large artery provides 
information about a major determinant of an unstable plaque i.e. the intra-plaque density of inflammatory cells such as macrophages [4, 5]; and third, the PET technique allows the noninvasive monitoring of relative changes in vascular inflammatory lesions in vivo over longer periods of time.

At an earlier stage, Rudd and coworkers had already reported that in patients with symptomatic carotid atherosclerosis uptake of ${ }^{18}$ FDG uptake in symptomatic lesions in the carotid wall was higher by $27 \%$ than in contra-lateral asymptomatic lesions [6]. Normal carotid arteries had no measurable ${ }^{18}$ FDG uptake at all. In 43 patients who underwent ${ }^{18}$ FDGPET for cancer screening the ${ }^{18}$ FDG uptake of the thoracic aorta and/or the carotid arteries were imaged as well. After randomization to either simvastatin or dietary management for 3 months, the simvastatin group-but not the diet group - had less ${ }^{18}$ FDG uptake in the aorta and/or carotid arteries compared to the initial uptake data [7]. Thus the well-known anti-inflammatory effect of simvastatin $[8,9]$ can be monitored by ${ }^{18}$ FDG-PET in a non-invasive way in vivo. The technique has to be combined with an imaging technique to visualize the anatomical structures such as CMR or multi-slice computed tomography (CT). As a stand-alone image modality, multi-slice CT is able to characterize lesion size and composition in coronary arteries [10-17], but the inflammatory component of the lesion is not yet identified specifically by this technique. The combination of ${ }^{18}$ FDG-PET with CMR or with multi-slice CT would allow imaging lesion size and lesion composition [18-38], particularly with respect to inflammatory cells that determine the vulnerability of the plaque [39-41]. Worthley and co-authors [1] are to be complimented for showing in a low number of relatively small animals changes in macrophage content of plaques in the aortic wall in response to continued cholesterol-containing diet (progression group) and in response to normal diet after 9 months of cholesterol-containing diet (regression group). Research aimed to stabilize plaques would have great benefit from vascular imaging using ${ }^{18}$ FDG-PET.

Open Access This article is distributed under the terms of the Creative Commons Attribution Noncommercial License which permits any noncommercial use, distribution, and reproduction in any medium, provided the original author(s) and source are credited.

\section{References}

1. Worthley SG, Zhang ZY, Machac J et al. (2008) In vivo noninvasive serial monitoring of FDG-PET progression and regression in a rabbit model of atherosclerosis. Int $\mathbf{J}$ Cardiovasc Imaging, in press

2. Ogawa M, Ishino S, Mukai T et al (2004) ${ }^{18}$ F-FDG accumulation in atherosclerotic plaques: immunohistochemical and PET imaging study. J Nucl Med 45:1245-1250

3. Zhang Z, Machac J, Helft G et al (2006) Non-invasive imaging of atherosclerotic plaque macrophage in a rabbit model with F-18 FDG PET: a histopathological correlation. BMC Nucl Med 6:3

4. Libby P (2000) Coronary artery injury and the biology of atherosclerosis: inflammation, thrombosis, and stabilization. Am J Cardiol 86(suppl J):3J-8J

5. Virmany R, Burke AP, Farb A et al (2002) Pathology of the unstable plaque. Prog Cardiovasc Dis 44:349-356

6. Rudd JHF, Warburton EA, Fryer TD et al (2002) Imaging atherosclerotic plaque inflammation with $\left[{ }^{18} \mathrm{~F}\right]$-fluorodeoxyglucose positron emission tomography. Circulation 105:2708-2711

7. Tahara N, Kai H, Ishibashi M et al (2006) Simvastatin attenuates plaque inflammation evaluation by fluorodeoxyglucose positron emission tomography. J Am Coll Cardiol 48:1825-1831

8. Libby P, Aikawa M (2003) Mechanisms of plaque stabilization with statins. Am J Cardiol 91(suppl B):4B-8B

9. Crisby M, Nordin-Fredriksson G, Shah PK, Yano J, Zhu J, Nilsson J (2001) Pravastatin treatment increases collagen content and decreases lipid content, inflammation, metalloproteinases, and cell death in human carotid plaques: implications for plaque stabilization. Circulation 103:926-933

10. Pundziute G, Schuijf JD, Jukema JW et al (2007) Noninvasive assessment of plaque characteristics with multislice computed tomography coronary angiography in symptomatic diabetic patients. Diabetes Care 30:1113-1119

11. Schuijf JD, Jukema JW, van der Wall EE, Bax JJ (2007) Multi-slice computed tomography in the evaluation of patients with acute chest pain. Acute Card Care 9:214-221

12. van Werkhoven JM, Schuijf JD, Jukema JW et al (2008) Anatomic correlates of a normal perfusion scan using 64slice computed tomographic coronary angiography. Am J Cardiol 101:404-405

13. Pundziute G, Schuijf JD, Jukema JW et al (2007) Prognostic value of multislice computed tomography coronary angiography in patients with known or suspected coronary artery disease. J Am Coll Cardiol 49:62-70

14. Schuijf JD, Pundziute G, Jukema JW et al (2006) Diagnostic accuracy of 64-slice multislice computed tomography in the noninvasive evaluation of significant coronary artery disease. Am J Cardiol 98:145-148

15. Schuijf JD, Wijns W, Jukema JW et al (2006) Relationship between noninvasive coronary angiography with multislice computed tomography and myocardial perfusion imaging. J Am Coll Cardiol 48:2508-2514

16. Jongbloed MR, Lamb HJ, Bax JJ et al (2005) Noninvasive visualization of the cardiac venous system using multislice computed tomography. J Am Coll Cardiol 45:749-753 
17. Achenbach S, Ropers D, Pohle FK et al (2004) The use of CTA in the chest pain center: a perspective. Crit Pathw Cardiol 3(2):87-93

18. Bax JJ, Lamb H, Dibbets P et al (2000) Comparison of gated single-photon emission computed tomography with magnetic resonance imaging for evaluation of left ventricular function in ischemic cardiomyopathy. Am J Cardiol 86:1299-1305

19. Langerak SE, Vliegen HW, de Roos A et al (2002) Detection of vein graft disease using high-resolution magnetic resonance angiography. Circulation 105:328-333

20. van der Wall EE, Heidendal GA, den Hollander W, Westera G, Roos JP (1980) I-123 labeled hexadecenoic acid in comparison with thallium-201 for myocardial imaging in coronary heart disease a preliminary study. Eur J Nucl Med 5:401-405

21. van Rugge FP, Holman ER, van der Wall EE, de Roos A, van der Laarse A, Bruschke AV (1993) Quantitation of global and regional left ventricular function by cine magnetic resonance imaging during dobutamine stress in normal human subjects. Eur Heart J 14:456-463

22. Tulevski II, Hirsch A, Sanson BJ et al (2001) Increased brain natriuretic peptide as a marker for right ventricular dysfunction in acute pulmonary embolism. Thromb Haemost 86:1193-1196

23. Braun S, van der Wall EE, Emanuelsson S, Kobrin I (1996) Effects of a new calcium antagonist, mibefradil (Ro 405967), on silent ischemia in patients with stable chronic angina pectoris: a multicenter placebo-controlled study. The mibefradil international study group. J Am Coll Cardiol 27:317-322

24. van Lennep JE, Westerveld HT, van Lennep HW, Zwinderman AH, Erkelens DW, van der Wall EE (2000) Apolipoprotein concentrations during treatment and recurrent coronary artery disease events. Arterioscler Thromb Vasc Biol 20:2408-2413

25. Bavelaar-Croon CD, Kayser HW, van der Wall EE et al (2000) Left ventricular function: correlation of quantitative gated SPECT and MR imaging over a wide range of values. Radiology 217:572-575

26. Bavelaar-Croon CD, Pauwels EK, van der Wall EE (2001) Gated single-photon emission computed tomographic myocardial imaging: a new tool in clinical cardiology. Am Heart J 141:383-390

27. Molhoek SG, Bax JJ, Bleeker GB et al (2004) Comparison of response to cardiac resynchronization therapy in patients with sinus rhythm versus chronic atrial fibrillation. Am J Cardiol 94:1506-1509

28. van der Wall EE, van Dijkman PR, de Roos A et al (1990) Diagnostic significance of gadolinium-DTPA (diethylenetriamine penta-acetic acid) enhanced magnetic resonance imaging in thrombolytic treatment for acute myocardial infarction: its potential in assessing reperfusion. Br Heart $\mathbf{J}$ 63:12-17

29. van Dijkman PR, van der Wall EE, de Roos A et al (1991) Acute, subacute, and chronic myocardial infarction: quantitative analysis of gadolinium-enhanced MR images. Radiology 180:147-151

30. Juwana YB, Wirianta J, Suryapranata H, de Boer MJ (2007) Left main coronary artery stenosis undetected by 64-slice computed tomography: a word of caution. Neth Heart J 15:255-256

31. Schuijf JD, Bax JJ, van der Wall EE (2007) Anatomical and functional imaging techniques: basically similar or fundamentally different? Neth Heart J 15:43-44

32. Wijpkema JS, Dorgelo J, Willems TP et al (2007) Discordance between anatomical and functional coronary stenosis severity. Neth Heart J 15:5-11

33. van de Wal RM, van Werkum JW, le Cocq d'Armandville MC et al (2007) Giant aneurysm of an aortocoronary venous bypass graft compressing the right ventricle. Neth Heart J 15:252-254

34. de Leeuw JG, Wardeh A, Sramek A, van der Wall EE (2007) Pseudo-aortic dissection after primary PCI. Neth Heart J 15:265-266

35. Henneman MM, Schuijf JD, Pundziute G et al (2008) Noninvasive evaluation with multislice computed tomography in suspected acute coronary syndrome: plaque morphology on multislice computed tomography versus coronary calcium score. J Am Coll Cardiol 52:216-222

36. Schuijf JD, Beck T, Burgstahler C et al (2007) Differences in plaque composition and distribution in stable coronary artery disease versus acute coronary syndromes; noninvasive evaluation with multi-slice computed tomography. Acute Card Care 9:48-53

37. Achenbach S (2008) Can CT detect the vulnerable coronary plaque? Int J Cardiovasc Imaging 24:311-312

38. Fayad ZA (2001) The assessment of the vulnerable atherosclerotic plaque using MR imaging: a brief review. Int $\mathbf{J}$ Cardiovasc Imaging 17:165-177

39. de Nooijer R, Von der Thüsen JH, Verkleij C et al (2006) Overexpression of IL-18 decreases intimal collagen content and promotes a vulnerable plaque phenotype in apolipoprotein-E-deficient mice. Arterioscler Thromb Vasc Biol 24:2313-2319

40. de Nooijer R, Verkleij CJ, Van der Thüsen JH et al (2006) Lesional overexpression of matrix metalloproteinase-9 promotes intraplaque hemorrhage in advanced lesions but not at earlier stages of atherogenesis. Arterioscler Thromb Vasc Biol 26:340-346

41. Groen HC, Gijsen FJ, van der Lugt A et al (2008) High shear stress influences plaque vulnerability. Neth Heart J $16: 283-290$ 